Д-ръ Н. М. Поповъ.

Орд. профессорь Императорскаго Новороссійскаго Университета.

\title{
ß $\mathrm{H}$ Ч
}

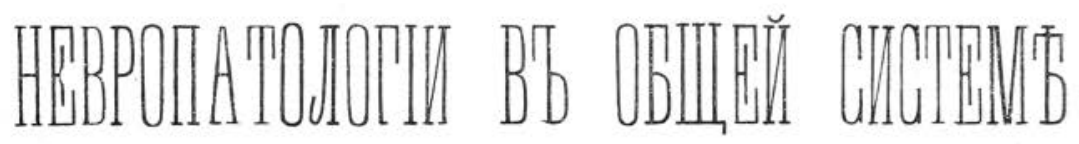

\section{МЕДИЦИНСКАГО ОБРАЗОВННІЯЯ.}

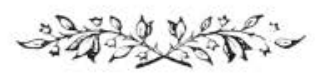

IF A 3 A I $\mathrm{B}$.

Типо-литографія И м п р ато р ск аг о университета.

1903. 
Іечатано по опредтленіп общества невронатодогов и психіатровъ цри И м п рат о р с ко з Казанскомь университеть.

За предсьдателя Н. М и сл а в к і й. 


\title{
Значеніе невропатологіи въ общей си- стемъ медицинскаго образованія ${ }^{1)}$.
}

\author{
Mм. Г२.!
}

Сегодняшняя лекція, моя первая лекція въ Новороссійскомъ Университеть, есть въ то же самое время первая, которая посвящается здъсь невропатологіи. Вдвойнъ естестведнымъ, поэтому, казалось мн危, избрать ея предметомъ одинъ изъ таких'ь вопросовъ, которые невольно возвикають у каждаго, приступающаго къ изученію новой для него области знавія.

Я буду говорить сегодня о значеніи невропатологіи въ общей системь медицинскаго образованія.

Современная невропатологія въ ея блестящемъ состояніи является почти исключительно плодомъ недавно минувшаго стольь⿻ія. Еще въ началь্ прошлаго вбка наука мало что знала о строеніи, функціяхъ и забольваніяхъ нервной системы. Ученые, коль скоро рбчь заходила о ней, категорически заявляли: „Textura obscura, functiones obscuriores, morbi obscurissimi “. Но особенво ярко недостатокъ научныхъ знаній сказывался въ психіатріи, этой заключительной, самой обширвой и самой сложной главъ невропатологіи. Въ ней не были сколько-вибудь опредъленно установлены даже основныя положенія. Шли еще горячіе споры о томъ, что нужно пови-

1) Ветупительная лекція, читанная въ Новороссійскомъ Университеть 20 сентября 1903 года. 
мать подь дупевными страданіями. Звачительная часть тогланнихь психіатровь склонна была смотрьть нанихь еще ст, метафизической или әтической точки зрьвія. 'Такъ, уже вь 20-хь годахт истекшаго стол单俰 Heinroth съ высоты про-

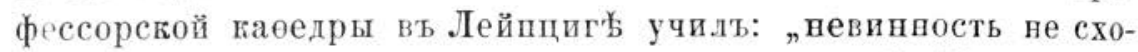
дить сь ума, а сходить сь ума только порокъ“. И подобнаго рода взгляды раздьлялись многими вылаюцимися диялелями того времени. Назову для примовра Benecke, Ideler'a.

Противь нихъ возставали приверженцы соматической школы, которые старались установить тохсную зависимость душевныхъ страданій отъ состоянія физическаго органвзма, хотя и подвергались ядовитым насмұшкамь своихь противниковъ, увърявшихт, что они идуть съ клистирными трубками на помоць кь помутившемуся уму. Правда, отпьльныя лица выдающихся дарованій (Esquirol въ Парижь, Nasse въ Бонн息 и др.) съ жаромь принялись уже за разработку ученія о нервншхъ и душевныхь забольваніяхь, но въ начал ихъ дығятельность не вызывала больпого сочувствія. Медидивскія школы того времеви давали свопмь слушателямт крайве скудныз, отрывочныя свбдынія по неврошатологік; въ большей части ихь не было отцильныхъ кафедрь, посвященныхъ әтой спедіальности, не было и соотвбтствующихь клиникь, гды желающіе могли-бы сь достаточнымъ удобствомь даблюдать и изучать картины вервныхь и душевныхь страданій. Съ такимъ печальнымъ положеніемь теоретической науки всепьло гармонировала и практическая жизнь. Если нервно-больные и на. ходили себ' пріють и кое-какое облегченіе въ тогдашвихъ больнидахь, то далеко нельзя сказать әтого же о душевнобольныхъ. Хотя спедіальныя заведевія для нихъ начали устраиваться давно, но әти заведевія скорбе имьли видъ тюремъ и казематовъ, назначенныхъ не для изльчченія больныхъ, a для изолированія опасныхь обществу субъектовъ. Здысь несчастные томились въ неволь⿱㇒㠯, перенося всевозможныя лишеніл, часто полуголодные, почти безь одежды, задыхаясь въ зловонномъ воздухь. При состояніяхъ возбужденія къ 


\section{$-5-$}

нимъ прим'ьяялись тьлесныя наказанія, а не помогали посльднія, на больного надьвали цвпи и приковывали къ стьвн. О сколько-нибудь раціональной терапіп не было и рбчи. Конечно, противь таких'ь порядковъ уже раздавались громгіе

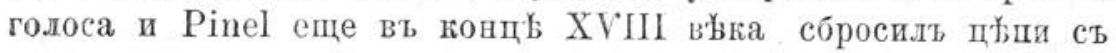
своихь больныхъ въ Bicetre' $\%$.. Но его примьрь долго оста. вался безъ подражателей и въ 1818 году Esquirol въ своемъ доклад' министру обрисоваль положеніе душевно-больныхъ во Франціи такими мрачными красками, передь которыми бльднъють всъ ужасы тогдашнихь тюремъ, а режимь въ нашихь дореформенныхъ желтыхъ домахъ смхло могъ быть названь образцомъ челов'ьколюбія и кротости.

Мм. Гг.! Мнъ пришлось пабросать передъ Вами очень печальную картину, и однако она отнюдь не страдаеть преувеличеніем'ь; если ее можно упрекнуть в'ь чемъ-либо, то развъ въ недостаточной яркости, и тьй не мене описанное мною положеніе дь́ль въ главныхъ своихъ чертахь удерживалось почти до половины XIX-го выка. Если Вы теперь сравните его с'ь окружающей нась дњйетвительностью, то самаго требовательнаго изь Вась не можеть не изумить происшедшая здъсь громадная перем'九на, совершившаяся вдобавокъ въ столь короткое время, въ теченіе всего нбсколькихъ десятильтій. Вь высшихь медидинскихь школахъ учреждены особыя кафедры вервныхъ и душевныхъ бользвей; при нихъ имьютея спеціальныя кливики, свабженвыя всьмь необходимымъ для изучевія вервной системы в' ея нормальномъ и больвненномъ состояніяхъ. Эти клипики перецолнены желающими учиться. Многіс изъ самыхъ выдающихся анатомовъ, гистолюговъ и физіологовъ всецъло посвятили себя изученію нервной системы. Всюду научная работа кипить горячим ключомт, съ каждымъ годомъ принося намъ новыя отқрытія, знакомя нась съ вовыми фактами фундаментальной важвости. Въ ваиболье крупныхъ научныхъ центрахъ вөзникли спеціальныя обцества невропатологовъ и психіатровъ, каковыхъ только въ нашемь отечеств в имется четыре. 
Неврологическая литература разрослась до гравдіозныхъ размъровъ. Журналовъ, посвященвыхъ исключительно невропатологіи, въ Россіи издается 4, въ Англіи 9, во Франпіи 11, въ Германіи 14. Однимт словомъ, невропатологи переживаютъ теперь періодъ крайне напряженной умственной работы, періодъ, подобный которому врядъ-ли можетъ представить исторія другой медидивской науки. И параллельво

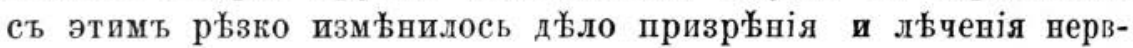
но и душевно-больныхъ. Въ каждой сколько-вибудь благоустроенной больницъ мы найдемъ теперь особое нервное отдъленіе и, какъ общее правило, оно обставлено обыкновенво съ исклюqительной заботливостью. Но въ большихъ городахъ уже не довольствуются ими: тамъ устраиваютъ больвицы, спеціально назваченныя только для льчченія нервныхъ страданій. Еще болье крупные успґхи мы видимъ въ терапіи и призръніи душевно-больныхъ. Прежнія тюрьмы отошли въ область преданія, мбесто ихъ заняли вполнъ благоустроенныя заведенія, нербдко имъъющія видъ дворцовъ, щецро снабженныя всъмя необходимымъ для удобства и даже комфорта ихъ обитателей. Такимт образомъ, перемъна всюду буквально поразительная. Невропатологія, еще такъ недавно почти игнорировавшаяся въ систем медицинскаго образованія, быстро выдвинулась ва одно изъ почетныхъ м'ьстъ. Неврологическая литература съ успљхом' соперничаеть со своими старшими сестрази. Частвыя лица, города, общивы, государства затрачивають громадныя суммы ва постройку спеціальныхъ больницъ. Невольно является вопросъ, что же все это значитъ, какіе мотивы заставили и людей науки и дъяттелей практической жизни столь единодушно приняться за разработку самыхъ разнообразныхъ вопросовъ, входящихъ въ область вевропатологіи.

Прежде всего пеобходимо признать, что между этими мотивами одва только любознательность играетъ сравнительно скромнуг роль. 
Правда, страдавія нервной системы подчасъ обнаруживаются такими картинами, передъ которыми невольно останавливается даже равнодушный зритель. Кому не тяжело видъть субъекта, бьющагося въ эпилептическихъ судорогахъ или мечущагося въ дикомъ припадкъ большой истеріи? Каждый испытываетъ непріятное ощущевіе, наблюдая больного, одержимаго Виттовой пляской или какой-нибудь формой тика. Но еще болъе внимавіе наблюдателя привлекаетъ матеріаль психіатрической влиники. Входя въ нее, уже на первыхъ же шагахь Вы сталкиваетесь съ рядомъ фавтовъ, полныхъ глубокаго, захватывающаго дупу интереса. Объясненіе многихъ загадочныхъ явленій нашего прошлаго, указапія, облегчающія намъ правильное понимавіе различныхъ вопросовъ настоящаго, предостереженія противъ грознаго будущаго,-со всъмъ этимъ веизбъжно встрђтится каждый мыслящій человжь, который проведетъ хоть нъсколько часовъ въ больниде для душевно-больныхъ. „Сколько матеріала для размышленій фдлософу, который посьтитъ пріютъ для душевно-больныхъ, гово-

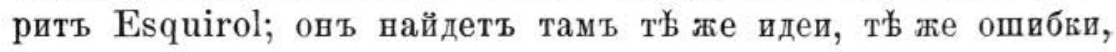
т店 же страсти; әто тотъ же міръ душевно-здоровыхт, только здъсь черты болъе рұзки, оттьнки болъе выражены, краски болґе ярки, потому что человъкъ здъсь во всей своей наготь'. Тжмъ не менъе при всемъ громадномъ теоретическомъ интересъ, представляемомъ невропатологіей, одного его было бы, разумъется, недостаточно, чтобы объяснить то рвеніе, съ какимъ начали разрабатывать эту науку за посльдднее время. Какъ прежде, такъ и теперь любознательность оказываетъ свое вліяніе только на отдыльныя лица.

Нельвя придавать слишкомъ большого значевія и прогрессу вспомогательныхъ наукъ, на выводы которыхъ опврается современный невропатологъ. Конечно, благодаря успъхамє аватоміи, гистологіи, физіологіи ему теперь стали болье ясными клиническіе симптомы; однако не слғвдуеть упускать изъ виду, что въ изв屯стной своей части эти успъхи обязаны именно запросамъ со сторовы бллиники. Даже и въ настоящее 
время можно назвать много такихь задачъ, которыя поставлены на очередь клиницистами и далеко еще не рышены теоретиками.

Итакь, мы ве можемъ привнать, чтобы о́ыстрый прогрессь въ ученіи о нервныхь и душевныхь бользпяхь вызывался одной только любознательностью и.ли завис'ьль отьь одного только развитія другихъ наукъ. Необходимо допустить шнов̆, б́лхе могучій факторь, который направиль мысль челов帝а на разработку нашей науки. И әтоть факторь будеть ясень для каждаго, кто дасть себ: трудъ пристальнске всмотрьться вь особенности нашей общественной и частной жизни.

Нашъ въкь принято называть нервнымъ. Дъйствительно, забольванія нервной системы вь современномь обществ встрьчаютсл все чаще и чаще, это положеніе мы легко можемь доказать данными точной науки, циффрами статистики. Правда, по отношенію къ нервнымъ бользнямь въ узкомъ смысль́ слова мы не обладаемъ пока большими числами, которыя позволяли бы вамь судить о степени заболюеваемости вь той

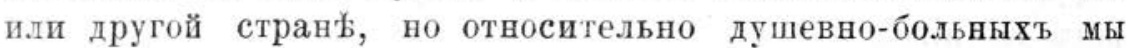
находимся въ несравненно болье благопріятныхъ условіяхъ. Вь Западной Европ安 почти всюду давно уже принято регистрировать душевно-больныхъ и теперь в' напемь распоряженіи находится цълый рядь весьма краснорьчивыхь цифрь. Приведу нбкоторыя изъ вихь.

Въ Великобританіи въ 1852 году ва 29197737 жителей насчитывалось 5๊ 525 душевно-больныхъ, т. е. 1,9 pro mille. Вь 1892 году число душевно-больныхь возрасло до 120004 , тогда какь все васеленіе равнялось 37732922, т. е. на 1000 душевно-здоровыхъ приходилось 3,18 душевно-больныхъ. Вь провиндіи Шлезвигь-Гольштейнъ въ 1803 на каждые 10000 жителей насчитывалось 11 душевно-больныхъ, въ 1840--28, а въ 1880-мь уже 34. Въ Финлявдіи въ 1880 году одивъ душевно-больной приходился на 470 жителей, въ 1891-мь одинь на 375. Эти цйфры настолько убодительны, qто не вуждаются в'ь комментаріяхь. Оньв категорически го- 
ворять намъ, что число душевно-больныхъ во всъхъ цивилизованныхъ странахь возростаетъ съ поразительной быстротой. И ве нужно быть особенно глубокимь философомъ, чтобы указать причвны такого печальнаго явленія. Наша общественпая жизнь сложилась в'ь высокой степени своеобразно. Стремленіе все размножающагося человычеста отыскивать себ́ новые источники существованія въ нашемь вик' встрбтилось съ зам'ьчательными успьхами въ области теоретическаго и прикладного званія; благодаря такому сочетанію людямъ стали извжстны невбдомыя досель области природы; такіл могучія силы ея, какъ электричество и парь, сдвлались послушным орудіемъ въ рукахъ человъка. Быстро и радикально измьнились поэтому самыя коренныя условія общественной жизни. Села и деревни начали пусть́ть, зато непомърно разрослось населеніе большихъ городовь; развитіе заводской и фабричной шромышленности достигло небывалой высоты; крайней напряженностыю отличается обшественная и политическая жизнь, развивая самолюбіе и честолюбіе отдыльныхъ лицъ. Борьба за существованіе становится все труднъе и труднъе и современному человъку прихолится затрачивать всь̈ свои силы, чтобы выйти поб'ддителемъ; но сплошь и рядомъ әтихъ силь оказывается ведостаточно; отсюда-потребность въ искусственныхъ возбудителяхъ; отсюда-т各 быстрые успиххи, какіе дълаеть въ нашемъ обществь распространеніе альоголя, әфира, морфія и другихъ лдовъ, въ конецт надламывающихъ и безъ того расшатанную нервную систему челово̆ға. Добавлю къ әтому, что какь бы люди ни напрягали свои силы въ жизненной борьб́, а плоды ея распредиялются между пими далеко не въ одинаковой степени. Въ одних классахъ населенія мы встрғчаемъ бъдность, нищету, горе, въ другихъизлашество, роскошь, пресыщевіе...

Но я слишкомъ далекь оть мысли набросать здъсь даже бльдную характеристику современваго общественнаго строя; мвь хотьлось только показать, почему әтоть строй предъявляеть все большіе и большіе запросы нашей псвхо-перв- 
ной организаціи и почему посльдняя, находясь въ столь не-

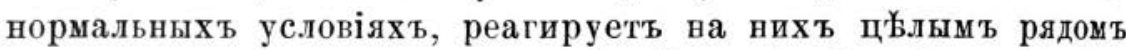
нервныхъ и душевныхъ страданій. Эти забольвавіл ежедневно выхватываютъ среди насъ вовыя и новыя жертвы и въ настоящее время являются грознымъ зломъ; съ ними настоятельно необходима самая энергичная борьба. Но для успьха посльдней нужно изучить ихъ хорошо, нужно знать, отчего они происходять? Воть здъсь то мы и имъемъ ключъ къ пониманію почему, какъ наука, такъ и практическая жизнь столь ревностно занялись разработкой невропатологіи и почему наша спедіальность такъ быстро выдвинулась среди другихъ отраслей клинической медицины: ее выдвинула горькая необходимость.

Изъ только что сказавнаго, пожалуй, можно вывести заключеніе, что изучать невропатологію должны липь ть врачи, которые имбють въ виду посвятить себя именно ей. Однако такой выводъ быль бы слишкомъ поспьшенъ. Наука o нервныхъ и дупевныхъ бользвяхъ имъетъ несравневно

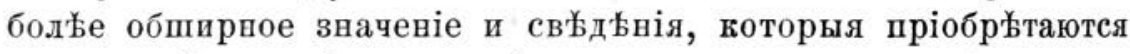
въ нервной и психіатрической клиникахъ, являются обязательно необходимыми для каждаго врача, на каждомь пагу его практической дъятельности.

Современная медицина выработала убъжденіе, что предупреждать бользви гораздо легче, чймъ бороться съ вими, когда он冬 уже развились. Невропатологія не представляетъ исключенія изъ общаго правила и здъсь профилактическія мхры въ состояніи принести несравненно болће пользы, чющъ самая искусная терапія уже возникшаго страдавія. Извєстно, напр., что прогрессивный параличъ помбшанвыхъ роковымъ образомъ уноситъ свои жертвы въ могилу, но мы имъемъ в本кія основанія думать, что принятыя во время мйры предосторожности могутъ надолго, если не навсегда, предотвратить развитіе әтой бользни. Неврастенія -бичъ современнаго цивилизованнаго человька, и не подлежить никакому сомнънію, что симптомы ея, захваченныя въ самомъ начал'ъ, безсльвдно 
исчезаютъ, если измьнить обстановку забольвающаго, устранить, хотя бы на время, вредные моменты. Но спеціалистъневропатологъ обыкновенно не можетъ рекомендовать профилактическихь м’ръ, не можетъ вазначить л'́ученія при самомъ возникновеніи бользни: къ вему обращаются только тогда, когда бъда на лицо и вдобавокъ уже достигла высокаго развитія. Совсъмъ иное-домашвій врачъ, врачъ, занимающійся общей практикой; онъ имъетъ случай ежедневно наблюдать своего падіента и подмбчать всъ перем'вы, какія въ немъ происходятъ; наконецъ, онъ долженъ понимать смысль и значеніе этихь перем'ьнъ.

Но свйдънія, которыя враqъ выносить изъ нервной и психіатрической кливикъ, ему необходимы и тогда, когда онъ встрбчается ве съ нервными бользвями. Нервная система, развъ̆тляясь во всемь организм' человъка, въ большей или меньшей степени вовлекается в’ь страдавіе при забольваніи самыхъ различныхъ органовъ. Воть почему таєъ или иначе врачу всегда необходимо съ вей считаться, особенно если его паціентъ уже ранъе обладаль впечатлительною психо-нервной организаціей. Боль-это одинъ изъ самыхъ обычныхъ симптомовь пораженія нервной системы, а какь часто она является главной жалобой соматическаго больного. Смягить боль, устранить ее иногда значить не только облегчить состояніе человъка, но даже избавить его оть смерти. Въ нервной клиникъ Вы найдете возможность основательно изучить, что такое боль, познакомиться со всъми ея влиническими разновидностями и съ тьми средствами, какими мы обладаемъ для ея увичтоженія. Безсонница, какъ извйстно, можеть осложнять собой самыя разнородныя бользвн; нерьдко, отличаясь упорствомъ, она истощаеть больного и тимъ задерживаеть его выздоровленіе; поэтому необходимо ее устранять. Но въ самой рłзкой формь безсонница наблюдается въ вервной и психіатрической клиникахъ. Здъсь, сльдовательно, съ больпимь удобствомъ можво выяснить условія, которыя ее вызывають, а также познакомиться и съ тьми методами, какіе ваука 
рекомендуеть для борьбы съ нею. Такимь образомь, изученіе общей невропатологіи необходимо для каждаго врача.

Но әтого мало.

Какой бы спеціальности врачъ себя ни посвятилт, овь на каждығ шагу будеть пуждаться вт основательномъ знаніи хотя бы главньйшихъ формь нервныхъ бользвей. Только при әтомь условіи овъ можеть вполнь правиль во понимать сложныл клиническія картины, съ какими ему нербдко шриходитея имьть дъљло; только тогда онъ можеть дать больноу дьйствительное облегченіе. Чтобы подкржиить свою мысль, приведу въсколько иримъровъ изъ будничной жизни. Кь гинекологу является больная съ жалобой на сильпыя боли вт нижней части живота. Изсльдованіе показываегъ с.табо выраженный параметрить. Назначается соотвьтствуюпее лфченіе. Чрезь нъсколько дней больная снова приходить кь врачу сь заявленіем'ь, что боли не только ве ослабьли, но даже усилились. Врачъ, не находя объективныхъ подтвержденій жалобамъ, успокаиваеть больную, вастапваеть ва дальн安шемъ лъченіи. Но боли достигаютъ вевыносимой степени и вызывають даже нервные припадки. Гинекологъ снова взсльдуеть свою паціентьу, находить, что въ половой сфферь нътт уже почти никакихъ измененій, и невольно склоненъ относиться къ заявленіямь больной сь полным недовъріемъ. А между тьмь больная продолжаеть страдать и будеть мучиться до тбхт порь, пока врачь пе ознакомится съ состояніемь ея нервной системы. Тогда онь встрбтится съ истерогенными точками и әта ваходка сразу разсъеть всь его ведоумьнія: онъ знаеть теперь, что его паціентка страдаетъ истеріей и, какь большинство истеричныхъ, отличается крайней чувствительностью. Получивь такія св歹днія, онъ можетъ создать совершенно иной плань л安ченія: ва первомь мьсть будуть поставлевы мыры, успогаивающія нервную систему, спеціальная же терапія или займет'ь второстепенное мъсто, или же ва время совсыљ будеть оставлена. При такомь льчченіи боли быстро успокаиваютя и больвая вскорь заявляеть, что она вполнег поцравилась. 
Другой примкръ: къ офотальмологу приходить больной и говоритъ, что у него нъсколько времени тому назадт начало

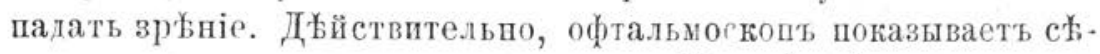
роватую окраску зрительваго соска. Но всы мърн, рекомендуемыя врачомъ-стрихнинъ, гальванизадія-остаются безрезультатными, - зржніе быстро продолжаеть падать. Если одвако врачъ, не ограничиваяск данными офтальмологическаго изсльдованія, выяснитъ состояніе остальной нервной системн, то встрбтится ст рядомъ симптомовъ, которые укажуть ему, что изм'ъневіе глазного дпа только деталь сложной кливической партвны. Онъ найдетъ у своего паціента отсутствіе кольнншхъ рефлексовъ, шаткую походку въ техноть, недержавіе мочи и другіе симптомы, вакіе ваблюдаются при спвпной сухотк'в.

Еще одинъ, посльдній, примьрғ: хирургъ видить передъ собою больную, которая сообщаетъ, что у вея опухоль грудпой железю. Изслждуя железу, врачъ убъждается, что она дьйствительво увеличена, бользнениа, а въ средин щупывается какой-то плотный узелъ. Прежде всего является мысль о новообразовавіи и объ операціи, какъ единственвомъ радикальномъ способ́ льчевів. Но если хирургъ хорошо знакомъ съ нервными страдавіями, то ввиманіе его невольно привлечетъ свособразная манера больной держать себя, стра甘ное отношеніе къ своему страдавію. Операдія откладывается, примвняется ль'ченіе гипнозомъ и въ короткое время отъ опухоли не остается и сльда.

До сихъ поръ я говорилъ о важности основательнаго знакомства съ нервной клиникой. Но не менъе важны занятія и въ клиник' психіатрической. Какимъ-бы спедіалистомъ врачъ ни былъ, онъ прежде всего имьеть дыло съ больнымъ человъкомъ, а мы зваемт, какъ ръзко иногда измйняется самочувствіе и настроеніе подъ вліяніем'ь болъзви: въ душу закрадываются мучительныя опасенія, развивается тоска; больпой становится раздражительным, вачинаеть дурно спать, утрачвваеть аппетитъ. Есть врачи, которыхь называютъ сча- 
стливыми, у воторыхъ больные поправляются быстръе, чйы у другихь. Это счастье врача въ значительной своей доль' есть ничто иное, какъ практичскій тактъ, какъ умьніе обращаться съ больными, внушить имъ вйру въ силу науки, въ свои собственныя знанія. И лучшей школой для выработку такого такта нужно назвать психіатрическую клинику: тутъ мы встрбчаемся съ наиболье ръзкими измьненіями настроенія, туть мы можемъ наблюдать, какъ они колеблются, какія вліянія ихъ усиливаютъ или, наобороть, сглаживаютъ.

Но свъдънія, которыя пріобр'ьтаетъ врачъ, изучая психіатрію, необходимы для него не только тогда, когда онъ находится у постели больного. Къ нему отовсюду могуть поступать вопросы, какіе овъ въ состолніи разрьшить лишь при томъ условіи, если изучаль психіатрію, работаль въ психіатрической клиникь. Съ такими запросами прежде всего обрацаются педагоги. Психіатрія и педагогія, пресльдуя раз. личныя задачи, съ перваго взгляда, казалось бы, не имбють ничего общаго, на самомъ дъл安 однако между ними очень много точекь соприкосновенія. Дити, происходящія изъ дегенеративной семьи или перенеспія в’ первые годы жизни какія-

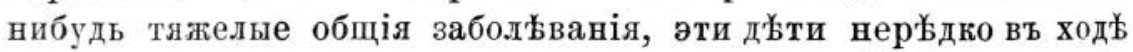
своего умственнаго развитія представляють ръзкія ук.ловенія отъ нормы. Такія уклоненія обыкновенно являются причиной, почему подобные субъекты далеко не всегда могуть быть воспитываемы въ нашихъ обычныхъ школахъ. Для нихъ необхо-

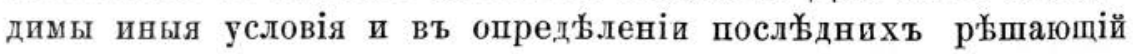
голось принадлежить психіатру. Наблюдая и изучая отсталыхъ, странныхъ дътей, психіатры пришли къ выводамъ, которые полны глубокаго практическаго значенія для педагогов'ъ. Такимъ образомъ, знакомство съ клинической психіатріей имбеть существенную важность и при выясненіи условій, въ которыхъ воспитываются нормальныя дъти. Психическій органъ ребенка отличается крайней чуткостью ко всъмъ получаемымъ впечатльніямъ. Вотъ почему характеръ ихъ оказываеть существенные вліянія на будущаго члена обцества, во 
многомъ опредъляя самое направленіе его дъятельности. Знаменитаго ботаника Линнея нъжно любящій отецъ еще съ колыбели окружаль цвъेтами, и трудно сомньваться, что ребенокъ, играя ими, именно тогда пристрастился къ изученію природы. Читая біографіи неккоторыхъ выдающихся композиторовъ, напр. Гайдна, Вы неръдко можете встрбтить указавія, какое глубокое впечатльніе производила на нихъ музыва даже въ возрасть самого нъжнаго дътства. Эти и подобные имъ факты наглядно подтверждають громадную роль воспитанія въ развитіи человъка. Если правильно веденное воспитаніе можеть сглаживать полученныя по насльдству бользненныя свойства и особенности, то, поставленное неправильно, ово въ состояніи расшатать психо-нервную организацію ребенка и подготовить благодарную почву; для развитія нервныхъ и душевныхъ забольвваній. У насъ въ Россіи въ самое посльљднее время школьный врачъ получиль право голоса въ педагогическихъ совътахъ. Этимъ фактомъ категорически признано зваченіе медицины въ ды实 воспитанія. Но чтобы быть достойнымъ своего положенія, чтобы приносить всю ту пользу, какую отъ него ждутъ, врачъ, какъ мы видьли выше, долженъ обладать основательнымъ знаніемъ шсихіатріи.

Не меньшей важностыо выводы психіатріи обладають и для юристовъ. Судебная практика учить, что на скамьљ подсудимыхъ все чаще и чаще шоявляются субъекты странные, лица крайне загадочныя, анализируя поступки воторыхъ, судьи отказываются рьшить, съ чбмъ они имьють дйло, съ нравственной ли испорчевностью, съ проявленіемъ ли страстей человька мало сдержаннаго или съ душевнымъ забольйавіемъ. На помощь они зовуть врача, ва долю котораго такимъ образомъ выпадаеть одна изъ самыхъ сложныхъ задачъ. А что такія задачи предлагають ему далеко не ръдко, вотъ въ доказательство нъсколько фактовъ. Въ Германіи на тысячу здороваго населенія приходится 3 душевно-больныхъ, въ германскихъ же тюрьмахъ это отношеніе увеличивается почти въ двадцать разъ. За двънадцать льъть дйятельности 
д-ра Томсона, врача Шотландской тюрьмы въ Пертћ, qрезъ его руки прошло около 430 убійцъ и изт нихь 40 были призвавы сумасшедшими. Въ Америк'ь число душевно-больныхъ между всьми арестантами достигаеть $8 \%$.

Мм. Гг. мн古 пришлось бы слишкомъ злоушотребить Вашимъ терпьніемъ, если бы я задумаль хотя и вт сжатомь очеркъ перечислить здъсь всъ вопросы, съ которыми современное общество обращаетса кь врачу вевропатологу, нуждаясь въ его спеціальныхъ знаніяхт. Но, я думаю и сказандаго мною достаточно, чтобы выяснить, какая видная роль выпала ва долю невропатологіи въ общей системь медицинскаго образовавія. Невропатологія представляеть собою не только простую спедіальность: подобно тому какь нервная система связываетъ различные органы, подобно әтому нервная клиника объедивяеть въ себ́ различвыя отрасли клинической медицины. Знакомство съ нервно-психической патологіей, и только оно одно, можеть придать медипинскимь знавіямь врача вадлежащу: цильность, а всему ето образованію тоть законченный философскій характеръ, который столь необходимъ для телов'ка, поставленнаго лицомъ къ лиду съ наиболье суровыми дилеммами современвой обцественной жизви. 